\title{
Independensi, Motivasi, Keahlian Profesional, Tingkat Pendidikan, Pengalaman Kerja dan Kinerja Pengawas Lembaga Perkreditan Desa
}

\author{
Komang Gede Arya Abdi Sentosa ${ }^{1}$ \\ Fakultas Ekonomi dan Bisnis \\ Universitas Udayana, Indonesia
}

\author{
Ketut Budiartha ${ }^{2}$ \\ Fakultas Ekonomi dan Bisnis \\ Universitas Udayana, Indonesia
}

\begin{abstract}
Surel : aryaabdi9@gmail.com
\section{ABSTRAK}

Tujuan dari penelitian ini adalah untuk memperoleh bukti empiris terkait pengaruh Independensi, Motivasi, Keahlian Profesional, Tingkat Pendidikan, dan Pengalaman Kerja pada Kinerja Pengawas internal. Penelitian ini dilakukan di 74 LPD di Kabupaten Klungkung. Teknik analisis data yang digunakan adalah regresi linier berganda. Hasil dari penelitian ini menunjukkan bahwa Independensi, Motivasi, Keahlian Profesional, Tingkat Pendidikan, dan Pengalaman Kerja berpengaruh positif dan signifikan terhadap kinerja pengawas internal. Hal ini menunjukan semakin tinggi Independensi, Motivasi, Keahlian Profesional, Tingkat Pendidikan, dan Pengalaman Kerja seorang pengawas maka kinerja pengawas tersebut akan semakin baik. Bagi pihak LPD hasil penelitian ini dapat memberikan informasi tambahan terkait faktor-faktor yang mempengaruhi kinerja pengawas internal, sehingga diharapkan dapat berguna dalam meningkatkan kinerja pengawas LPD di Kabupaten Klungkung.
\end{abstract}

Kata Kunci: Independensi; Motivasi; Keahlian Profesional; Tingkat Pendidikan; Pengalaman Kerja.

\section{Independence, Motivation, Professional Skills, Education Level, Work Experience and Performance of LPD Supervisors}

\begin{abstract}
The purpose of this study is to obtain empirical evidence related to the influence of Independence, Motivation, Professional Skills, Level of Education, and Work Experience on Internal Supervisor Performance. This research was conducted in 74 LPD in Klungkung Regency. The data analysis technique used is multiple linear regression. The results of this study indicate that Independence, Motivation, Professional Skills, Level of Education, and Work Experience have a positive and significant effect on the performance of internal supervisors. This shows the higher independence, motivation, professional expertise, education level, and work experience of a supervisor, the supervisor's performance will be better. For the LPD the results of this study can provide additional information related to factors that influence the performance of internal supervisors, so it is expected to be useful in improving the performance of LPD supervisors in Klungkung Regency.
\end{abstract}

Keywords: Independence; Motivation; Professional Expertise; Level Of Education; Work Experience.

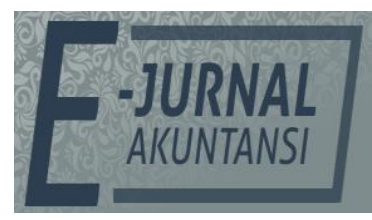

e-ISSN 2302-8556

Vol. 31 No. 3

Denpasar, Maret 2021

Hal. 652-666

DOI:

10.24843/EJA.2021.v31.i03.p10

PENGUTIPAN:

Sentosa, K.G.A.A., \& Budiartha, K. (2021).

Independensi, Motivasi,

Keahlian Profesional,

Tingkat Pendidikan,

Pengalaman Kerja dan

Kinerja Pengawas Lembaga

Perkreditan Desa. E-Jurnal

Akuntansi, 31(3), 652-666

RIWAYAT ARTIKEL:

Artikel Masuk:

15 Mei 2020

Artikel Diterima:

17 Juli 2020

Artikel dapat diakses : https://ojs.unud.ac.id/index.php/Akuntansi/index 


\section{PENDAHULUAN}

Pengawas internal LPD sebagaimana yang tertuang dalam pasal 1 ayat (11) Peraturan Daerah Provinsi Bali No. 3 tahun 2017, Panureksa (pengawas internal) adalah pengawas internal yang dibentuk oleh Desa Pakraman bertugas melakukan pemeriksaan terhadap pengelolaan LPD. Pengawas internal LPD adalah pengendalian intern yang ada di dalam LPD, merupakan aktivitas yang dilakukan oleh orang yang diberikan tugas untuk mengawasi pelaksanaan operasi sesuai dengan hasil pararem atau keputusan desa adat. Khususnya keputusan yang menyangkut organisasi serta tugas lainnya seperti mengawasi dan melakukan pemeriksaan terhadap suatu kebijakan yang disepakati oleh pengurus termasuk menilai efektif tidaknya suatu prosedur dan penyimpanganpenyimpangan yang terjadi pada suatu kebijakan yang telah ditetapkan dan dijalankan oleh pengurus (Putra \& Rasmini, 2014).

Sebagai penunjang keberhasilan dalam menjalankan tugas dan fungsinya, sangatlah diperlukan kinerja auditor yang baik dan berkualitas (Dedik et al., 2014). Kinerja dapat diukur dengan pengukuran tertentu (standar), yang dimana kualitas berkaitan dengan mutu kerja yang dihasilkan, sedangkan kuantitas adalah jumlah hasil kerja yang dihasilkan dalam kurun waktu tertentu, dan ketepatan waktu adalah kesesuaian waktu yang telah direncanakan, untuk menghasilkan kinerja yang memuaskan seorang pengawas internal harus memiliki sikap yang jujur dan independen yang diterapkan dalam melaporkan hasil pengawasan (Prawitasari \& Badera, 2015). Tugas dan wewenang yang kompleks dari pengawas internal LPD menuntut memiliki eksistensi yang tinggi.

Dalam menjankan tugasnya sikap independensi sangat mempengaruhi kinerja seorang pengawas. Independensi dalam hal ini adalah seorang pengawas harus terbebas dari intervensi pihak-pihak yang memiliki kepentingan atas laporan keuangan dalam kaitanya untuk pengambilan keputusan. Pengawas harus bertindak secara objektif dan integritas yang tinggi dalam melaksanakan tugas sehingga dapat menciptakan pengawasan jujur dan tidak memihak dalam menilai dan mengambil kebijakan (Kodyawati \& Dewi, 2019). Hasil audit perusahaan sangat berpengaruh nantinya pada keputusan dari manajeman atau pengurus untuk melanjutkan arah tujuan perusahaan di tahun berikutnya (Mukuru \& Kiruja, 2013). Seorang auditor ataupun pengawas harus memelihara integritasnya dan objektivitas dalam tugasnya, sehingga kinerja pengawas internal dalam pelaksanaan pengawasannya dapat dilaksanakan secara efektif (Putra \& Jati, 2019)

Selain sikap independensi, motivasi juga memiliki pengaruh yang besar terhadap kinerja seorang pengawas. Motivasi adalah suatu faktor yang mendorong seseorang untuk melakukan suatu aktivitas tertentu. Teori motivasi yang telah dikembangkan oleh Maslow menjelasakan bahwa motivasi dipicu oleh usaha manusia untuk memenuhi kebutuhan (Robbins \& Timothy, 2015). Motivasi merupakan salah satu faktor yang cukup penting pada kualitas hasil dari pekerjaan yang dihasilkan seseorang dalam menjalankan pekerjaannya, terutama untuk seorang auditor yang sering kali menjadikan motivasinya sebagai dorongan untuk menghasilkan laporan audit yang (Mardika \& Suartana, 2019). Motivasi kerja merupakan salah satu aspek perilaku psikologis karyawan, motivasi merupakan akibat dari interaksi karyawan dan situasi (Krisnawati \& 
Suartana, 2017). Motivasi dapat membuat seseorang mempunyai semangat juang yang tinggi ntuk meraih tujuan dan memenuhi standar yang ada. Semakin tinggi motivasi pengawas internal, semakin membantu pengawas dalam menjalankan tugasnya (Bhuwaneswari \& Damayanthi, 2018).

Pengawas LPD dalam menjalankan tugasnya dituntut untuk memiliki keahlian professional. Keahlian profesional adalah tingkat kemahiran dan kecermatan profesionalnya dalam melakukan pemeriksaan terhadap penerapan struktur pendendalian (Bhuwaneswari \& Damayanthi, 2018). Profesionalisme meliputi kemampuan penguasaan baik secara teknis, maupun secara teoritis bidang keilmuan dan keterampilan yang berhubungan dengan tugasnya, sebagai pemeriksa (Usman et al., 2014). Keahlian professional seorang pengawas dapat dilihat dari tingkat efektivitas, kecermatan dan kesungguhannya dalam melaksanakan tugasnya dan fungsinya.

Tingkat pendidikan dan pelatihan kerja sangat penting dalam meningkatkan kualitas kerja karyawan (Wulandari \& Latrini, 2018). Pendidikan membentuk dan menambah pengetahuan seseorang pengawas untuk mengerjakan sesuatu dengan baik dan lebih cepat (Kodyawati \& Dewi, 2019). Semakin banyak pengetahuan yang diperoleh memudahkan auditor internal (Pengawas) untuk melaksanakan tugasnya sehingga dapat mengefktifkan pengendalian internal entintas (Mahendra \& Ramantha, 2018). Pengawas internal diukur melalui tingkat pendidikan terakhir yang dimiliki karena disamping pengalaman, semakin tinggi tingkat pendididkan yang dimiliki seorang pengawas, maka pengetahuan yang diperoleh semakin banyak dan dapat mengadakan pengawasan dengan baik (Bhuwaneswari \& Damayanthi, 2018).

Sebagai seorang pengawas, pengalaman kerja merupakan hal yang harus dimiliki. Menurut (Usman, 2015) tugas yang berbasis pengalaman dapat mengembangkan hasil kinerja seseorang dalam menjalankan tugas. Semakin lama masa kerja yang dimiliki seorang auditor internal maka kompetensi auditor internal dan kualitas hasil auditnya akan semakin baik, sehingga mencerminkan pengendalian internal yang baik pula (Mahendra \& Ramantha, 2018). Pengalaman kerja merupakan tingkat penguasaan pengetahuan serta keterampilan seseorang dalam pekerjaannya yang dapat diukur dari masa kerja dan dari tingkat pengetahuan serta keterampilan yang dimiliki (Murtini \& Juliarsa, 2017). Dengan pengalaman yang dimiliki dibidangnya seorang pengawas dapat mendukung kecepatan dalam mendeteksi kesalahan dan keterampilan serta ketelitian dalam menjalankan tugas dan fungsinya. Semakin tinggi tingkat pengalaman seseorang maka kinerja pengawas internal yang dihasilkan pun akan semakin baik (Putra \& Jati, 2019). Dengan pengalaman kerja yang dimiliki oleh seorang pegawai, maka pekerjaan yang dihasilkan dapat lebih baik daripada mereka yang belum mempunyai pengalaman dibidang ini (Wulandari \& Latrini, 2018). Hal ini dapat dijadikan rekomendasi bahwa semakin lama masa kerja yang dimiliki oleh seorang auditor, maka akan semakin baik kualitas hasil pemeriksaan auditor tersebut (Masrizal, 2010).

Penelitian ini dilakukan karena terdapat permasalahan-permasalahan yang dialami oleh LPD di Bali dan hasil penelitian terdahulu yang tidak konsisten pada beberapa variabel, seperti pada variabel Independensi, Keahlian 
Profesional, dan Pengalaman Kerja. (Widyantara et al., 2017), dan (Kodyawati \& Dewi, 2019) dalam penelitian menyatakan Independensi berpengaruh positif terhadap kinerja pengawas, sedangkan (Bhuwaneswari \& Damayanthi, 2018) dalam penelitiannya menyatakan Independensi terbukti tidak berpengaruh pada efektivitas pengendalian internal LPD di Kota Denpasar. (Wulandari \& Dharma, 2018), dalam penelitiannya menyatakan Keahlian Profesional berpengaruh positif terhadap kinerja internal auditor dan (Putra \& Jati, 2019) dalam penelitiannya menyatakan keahlian profesional berpengaruh positif terhadap kinerja pengawas LPD di Kecamatan Abiansemal, sedangkan (Bhuwaneswari \& Damayanthi, 2018) menyatakan keahlian professional terbukti tidak berpengaruh pada efektivitas pengendalian internal LPD di Kota Denpasar. (Kodyawati \& Dewi, 2019) dalam penelitiannya menyatakan pengalaman kerja berpengaruh positif terhadap kinerja pengawas koperasi di Kabupaten Klungkung, hal ini juga didukung oleh penelitian (Putra \& Jati, 2019) menyatakan pengalaman kerja berpengaruh positif terhadap kinerja pengawas internal LPD. Sedangkan (Dhiaa \& Thuraiya, 2017) dalam penelitiannya menyatakan pengalaman kerja tidak berpengaruh pada efektivitas pelaksanaan audit internal. Selain itu (Bouhawia et al., 2015) menyatakan bahwa pengalaman kerja tidak berpengaruh pada hasil audit dan hanya menghasilkan efek yang berlawanan pada integeritas auditor. Penelitian ini dilakukan di Kabupaten Klungkung, dimana menurut data dari BKS LPLPD Kabupaten Klungkung dari 119 LPD yang ada di Kabupaten Klungkung terdapat 6 LPD yang tidak beroperasi, 1 LPD dinyatakan tidak sehat, 8 LPD di kategorikan kurang sehat, 24 dinyatakan cukup sehat dan sisanya sebanyak 80 LPD dinyatakan sehat.

(Widyantara et al., 2017) menyatakan dalam penelitiannya independensi berpengaruh positif terhadap kinerja badan pengawas LPD di kecamatan Buleleng. (Rahayu \& Suryono, 2016) dalam penelitiannya menyatakan bahwa seorang auditor dipengaruhi oleh independensi dalam menjalankan tugasnya. (Đorđević \& Đukić, 2017) menyatakan bahwa independensi berpengaruh positif pada efektivitas auditor internal. (Kodyawati \& Dewi, 2019) dalam penelitiannya menyatakan independensi berpengaruh positif terhadap kinerja pengawas. Sedangkan (Bhuwaneswari \& Damayanthi, 2018) hasil penelitiannya menyatakan hasil pengujian independensi terbukti tidak berpengaruh pada efektivitas pengendalian internal LPD di Kota Denpasar

Melalui sikap independen seorang pengawas harus bebas dari tekanan apapun. Dengan demikian sikap independen penting dan harus dijunjung tinggi oleh seorang pengawas.

$\mathrm{H}_{1}$ : Independensi berpengaruh positif terhadap kinerja pengawas LPD di Kabupaten Klungkung.

Atribusi merupakan proses mempelajari bagaimana seseorang menyikapi suatu suatu peristiwa dan menjelaskan penyebab atas perilakunya (Suartana, 2010). Motivasi kerja merupakan salah satu penyebab perilaku seseorang pengawas internal yang berasal dari dalam diri pengawas. Menurut teori hirarki Maslow jika pekerjaan telah mampu memenuhi beberapa kebutuhan yang lebih tinggi maka hal tersebut akan menentukan dalam motivasi kerja. (Widyantara et al., 2017) menyebutkan bahwa salah satu faktor yang mempengaruhi kinerja dari badan pengawas LPD di kecamatan Buleleng adalah motivasi. (Kodyawati \& 
Dewi, 2019) dalam penelitiannya menyatakan motivasi berpengaruh positif terhadap kinerja pengawas koperasi.

$\mathrm{H}_{2}$ : Motivasi kerja berpengaruh positif terhadap kinerja pengawas LPD di Kabupaten Klungkung.

(Rahayu \& Suryono, 2016) dalam penelitiannya menyatakan bahwa keahlan professional berpengaruh positif terhadap kualitas kinerja auditor. (Mappanyuki, 2016) dalam penelitiannya menyebutkan bahwa keahlian professional berpengaruh positif terhadap kompleksitas kinerja seorang auditor. Penelitian (Wulandari \& Dharma, 2018) menunjukkan hasil profesionalisme berpengaruh positif dan signifikan terhadap kinerja internal auditor. (Putra \& Jati, 2019) hasil penelitiannya menyatakan profesionalisme berpengaruh positif dan signifikan pada kinerja pengawas internal LPD di Kecamatan Abiansemal Kabupaten Badung. Sedangkan hasil penelitian (Bhuwaneswari \& Damayanthi, 2018) menyatakan hasil pengujian keahlian profesional terbukti tidak berpengaruh pada efektivitas pengendalian internal LPD di Kota Denpasar. Pengawas yang memiliki keahlian berdasarkan jabatan yang diperoleh saat ini, akan mempermudah dalam menemukan kekeliruan maupun indikasi penyelewengan dari pengendalian internal.

$\mathrm{H}_{3}$ : Keahlian professional berpengaruh positif terhadap kinerja pengawas LPD di Kabupaten Klungkung.

Atribusi merupakan proses mempelajari bagaimana seseorang menyikapi suatu suatu peristiwa dan menjelaskan penyebab atas perilakunya (Suartana, 2010). Pendidikan merupakan saah satu penyebab perilaku seorang pengawas yang berasal dari dalam diri pengawas. Pendidikan merupakan indicator internal dalam menjelaskan bagaimana seorang pengawas menjelaskan perilkaunya melalui tugas dan wewenang yang dimilikinya. Pengetahuan diukurdari seberapa tinggi pendidikan seorang auditor. Seorang pengawas LPD dalam melaksanakan kegiatan pengawasan harus memiliki pendidikan, keahlian dan disiplin. Pengawas LPD yang memiliki pengetahuan akan bekerja lebih teliti dan dapat dengan cepat mengetahui penyimpangan yang terjadi dalam melaksanakan pengawasan.

Hal ini diungkapkan dalam penelitian (Widyantara et al., 2017) yang dilakukan pada pengawas LPD di kecamatan Buleleng. Variabel pendidikan dinyatakan berpengaruh positif terhadap kinerja pengawas LPD di kecamatan Buleleng. (Bouhawia et al., 2015) menyebutkan bahwa tingkat pendidikan berpengaruh pada hasil audit. Penelitian yang dilakukan (Kotur \& Anbazhagan, 2014) mengungkapkan bahwa factor pendidikan berpengaruh pada efektivitas kerja yang dilaksanakan. Hal ini juga didukung oleh penelitian yang dilakukan (Kodyawati \& Dewi, 2019) bahwa tingkat pendidikan berpengaruh positif dan signifikan terhadap kinerja pengawas. Sehingga, pendidikan sangat penting bagi auditor karena dengan pengetahuan yang dimiliki akan mempermudah dalam melakukan pemeriksaan audit.

$\mathrm{H}_{4}$ : Tingkat pendidikan berpengaruh positif terhadap kinerja pengawas LPD di Kabupaten Klungkung.

Atribusi merupakan proses mempelajari bagaimana seseorang menyikapi suatu suatu peristiwa dan menjelaskan penyebab atas perilakunya (Suartana, 2010). Pengalaman kerja merupakan indicator internal dalam menjelaskan 
bagaimana seorang pengawas menjelaskan perilakunya melalui tugas dan wewenang yang dimilikinya. Pengalam kerja merupakan factor yang penting dalam memprediksi dan menilai kinerja internal auditor dalam melakukan pemerikasaan intern. Pengawas yang berpengalaman akan lebih cepat dan tanggap dalam mendeteksi kekeliruan yang terjadi.

Hal ini dibuktikan oleh penelitian yang dilakukan oleh (Kodyawati \& Dewi, 2019) yang menunjukan bahwa pengalaman kerja berpengaruh positif terhadap kinerja pengawas. (Kotur \& Anbazhagan, 2014) menyatakan bahwa pengalaman kerja akan meningkatkan efektivitas dalam bekerja namun pengalam kerja mengalami penurunan pada karyawan lama. (Bhuwaneswari \& Damayanthi, 2018) hasil penelitiannya menyatakan bahwa Pengalaman kerja terbukti berpengaruh positif pada efektivitas pengendalian internal LPD di Kota Denpasar. Hasil penelitian dari (Putra \& Jati, 2019) menyatakan pengalaman kerja berpengaruh positif dan signifikan pada kinerja pengawas internal LPD di Kecamatan Abiansemal Kabupaten Badung. Sedangkan (Dhiaa \& Thuraiya, 2017) dalam penelitiannya yang mana salah satu variabel independennya adalah pengalaman kerja tidak berpengaruh pada efektivitas pelaksanaan audit internal. (Bouhawia et al., 2015) menyebutkan bahwa pengalaman kerja tidak berpengaruh pada hasil audit dan hanya menghasilkan efek yang berlawanan pada integritas auditor.

$\mathrm{H}_{5}$ : Pengalaman kerja berpengaruh positif terhadap kinerja pengawas LPD di Kabupaten Klungkung.

\section{METODE PENELITIAN}

Lokasi penelitian ini dilakukan pada LPD di Kabupaten Klungkung. Responden dalam penelitian ini adalah pengawas internal LPD di Kabupaten Klungkung yang mengetahui tugas, wewenang dan fungsinya dalam menilai efektivitas pengendalian internal. Obyek dari penelitian ini adalah kinerja yang dipengaruhi oleh independensi, motivasi, keahlian professional, tingkat pendidikan dan pengalaman kerja pengawas internal pada LPD di Kabupaten Klungkung.

Populasi dalam penelitian ini adalah seluruh LPD yang berada di Kabupaten Klungkung. Jumlah LPD yang ada di Kabupaten Klungkung adalah 119 buah. Metode pengambilan sampel dalam penelitian ini menggunakan metode purposive sampling. Kriteria yang ditetapkan untuk penentuan sampel antara lain adalah LPD yang memiliki jumlah asset lebih dari 2 miliar rupiah.

Dari 119 LPD yang berada di Kabupaten Klungkung hanya 74 LPD yang memenuhi kriteria penelitian, yaitu memiliki asset diatas 2 miliar rupiah. Responden dalam penelitian ini adalah pengawas internal LPD di Kabupaten Klungkung, dalam penelitian ini dipilih ketua atau salah satu anggota pengawas internal di setiap LPD di Kabupaten Klungkung.

Penelitian ini menggunakan teknik regresi linear berganda untuk pengolahan dengan bantuan program SPSS. Teknik ini digunakan untuk mengetahui pengaruh antara variable bebas terhadap variable terikatnya. Persamaan regresi dalam penelitian ini adalah :

$$
Y=\alpha+\beta_{1} X_{1}+\beta_{2} X_{2}+\beta_{3} X_{3}+\beta_{4} X_{4}+\beta_{5} X_{5}+\varepsilon
$$




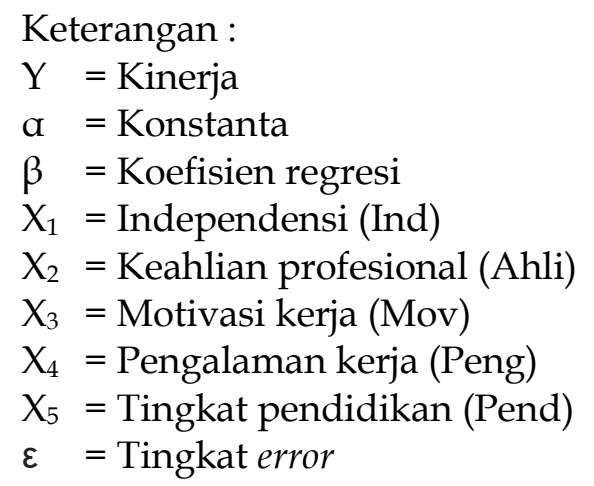

\section{HASIL DAN PEMBAHASAN}

Statistik Deskriptif digunakan untuk memberikan gambaran atau deskriptif suatu data yang dilihat dari nilai rata-rata (mean), nilai minimum, nilai maksimum, dan nilai dari data penelitian. Hasil dari pengujian statistik deskriptif dari masing-masing variabel penelitian disajikan pada Tabel 1.

Tabel 1. Hasil Uji Statistik Deskriptif

\begin{tabular}{llllll}
\hline Variabel & $\mathrm{N}$ & Minimum & Maximum & Mean & Std. Deviation \\
\hline Independensi & 74 & 9 & 16 & 13.89 & 1.869 \\
Motivasi & 74 & 8 & 12 & 10.42 & 1.250 \\
Keahlian Profesional & 74 & 9 & 16 & 13.01 & 1.756 \\
Tingkat Pendidikan & 74 & 7 & 12 & 10.16 & 1.481 \\
Pengalaman Kerja & 74 & 13 & 24 & 20.20 & 2.239 \\
Kinerja Pengawas Internal & 74 & 11 & 20 & 18.35 & 2.407
\end{tabular}

Sumber: Data Penelitian, 2020

Nilai rata-rata variabel independensi LPD di kabupaten Klungkung sebesar 13,89. Nilai minimum dan maksimum independensi LPD di kabupaten Klungkung paling rendah sebesar 9 dan paling tinggi sebesar 16.

Nilai rata-rata variabel motivasi LPD di kabupaten Klungkung sebesar 10,42. Nilai minimum dan maksimum motivasi LPD di kabupaten Klungkung paling rendah sebesar 8 dan paling tinggi sebesar 12 .

Nilai rata-rata variabel keahlian profesional LPD di kabupaten Klungkung sebesar 13,01. Nilai minimum dan maksimum keahlian profesional LPD di kabupaten Klungkung paling rendah sebesar 9 dan paling tinggi sebesar 16.

Nilai rata-rata variabel tingkat pendidikan LPD di kabupaten Klungkung sebesar 10,16. Nilai minimum dan maksimum tingkat pendidikan LPD di kabupaten Klungkung paling rendah sebesar 7 dan paling tinggi sebesar 12.

Nilai rata-rata variabel pengalaman kerja LPD di kabupaten Klungkung sebesar 20,20. Nilai minimum dan maksimum pengalaman kerja LPD di kabupaten Klungkung paling rendah sebesar 13 dan paling tinggi sebesar 24 .

Nilai rata-rata variabel kinerja pengawas internal LPD di kabupaten Klungkung sebesar 18,35. Nilai minimum dan maksimum kinerja pengawas internal LPD di kabupaten Klungkung paling rendah sebesar 11 dan paling tinggi sebesar 20 .

Model analisis regresi linear berganda digunakan untuk mendapat koefisien regresi yang akan menentukan apakah hipotesis yang dibuat akan diterima atau ditolak. Hasil analisis ini mengacu pada hasil pengaruh variabel 
Independensi $\left(X_{1}\right)$, variabel Motivasi $\left(X_{2}\right)$, variabel Keahlian Profesional $\left(X_{3}\right)$ variabel Tingkat Pendidikan $\left(\mathrm{X}_{4}\right)$ terhadap Kinerja Pengawas Internal (Y) LPD di Kabupaten Klungkung Adapun hasil analisis regresi dengan program Statitical Pacage of Social Science (SPSS) versi 21.0 for Windows dapat dilihat pada Tabel 2 berikut:

Tabel 2. Rangkuman Hasil Analisis Regresi Linear Berganda

\begin{tabular}{llllll}
\hline \multirow{2}{*}{ Model } & \multicolumn{2}{l}{$\begin{array}{l}\text { Unstandardized } \\
\text { Coefficients }\end{array}$} & $\begin{array}{l}\text { Standardized } \\
\text { Coefficients }\end{array}$ & $\mathrm{t}$ & \multirow{2}{*}{ Sig. } \\
\cline { 2 - 4 } & $\mathrm{B}$ & Std. Error & Beta & & \\
\hline (Constant) & -5.406 & 2.740 & & -1.973 & 0.053 \\
Independensi & 0.294 & 0.112 & 0.228 & 2.636 & 0.010 \\
Motivasi & 0.405 & 0.189 & 0.210 & 2.140 & 0.036 \\
Keahlian Profesional & 0.593 & 0.116 & 0.433 & 5.113 & 0.000 \\
Tingkat Pendidikan & 0.309 & 0.136 & 0.190 & 2.271 & 0.026 \\
Pengalaman Kerja & 0.228 & 0.105 & 0.212 & 2.164 & 0.034 \\
\hline
\end{tabular}

Sumber: Data Penelitian, 2020

Berdasarkan Tabel 2, dapat ditulis persamaan regresi linear berganda sebagai berikut.

$$
Y=-5,406+0,294 X_{1}+0,405 X_{2}+0,593 X_{3}+0,309 X_{4}+0,228 X_{5}
$$

Nilai konstanta benilai negatif sebesar -5.406 maka dapat diartikan apabila tidak terdapat pengaruh dari variabel lain atau variable bebas, maka nilai konstan dari variabel kinerja (Y) adalah sebesar-5.406.

Nilai koefisien variable independen $\left(X_{1}\right)$ bernilai positif sebesar 0,294 hal ini menunjukkan bahwa apabila nilai independensi meningkat satu satuan dengan anggapan bahwa variable lainnya konstan maka kinerja pengawas internal akan mengalami peningkatan sebesar 0,294.

Nilai koefeisien variable motivasi $\left(X_{2}\right.$ ) bernilai positif sebesar 0,405 hal ini menunjukkan bahwa apabila nilai motivasi meningkat satu satuan dengan anggapan bahwa variable lainnya konstan maka kinerja pengawas internal akan mengalami peningkatan sebesar 0,405.

Nilai koefisien variable keahlian professional $\left(X_{3}\right)$ bernilai positif sebesar 0,593 hal ini menunjukkan bahwa apabila nilai keahlian profesional meningkat satu satuan dengan anggapan bahwa variable lainnya konstan maka kinerja pengawas internal akan mengalami peningkatan sebesar 0,593.

Nilai koefisien variabel tingkat pendidikan $\left(X_{4}\right)$ bernilai positif sebesar 0,309 hal ini menunjukkan bahwa apabila nilai tingkat pendidikan meningkat satu satuan dengan anggapan bahwa variable lainnya konstan maka kinerja pengawas internal akan mengalami peningkatan sebesar 0,309.

Nilai koefisien variabel pengalaman kerja $\left(X_{5}\right)$ bernilai positif sebesar 0,228 hal ini menunjukkan bahwa apabila nilai pengalaman kerja meningkat satu satuan dengan anggapan bahwa variable lainnya konstan maka kinerja pengawas internal akan mengalami peningkatan sebesar 0,309.

Analisis derteminasi dilakukan untuk mengetahui sejauh mana variasi variabel bebas yaitu $X_{1}$ (Independensi), $X_{2}$ (Motivasi) $X_{3}$ (Keahlian Profesional), $\mathrm{X}_{4}$ (Tingkat Pendidikan) $\mathrm{X}_{5}$ (Pengalaman kerja) terhadap variabel Kinerja Pengawas Internal (Y). berdasarkan hasil spss yang dapat dilihat pada Tabel 2. 
Tabel 3. Analisis Determinasi

\begin{tabular}{|c|c|c|c|c|}
\hline Model & $\mathrm{R}$ & R Square & Adjusted R Square & $\begin{array}{l}\text { Std. Error of the } \\
\text { Estimate }\end{array}$ \\
\hline 1 & $0.739^{a}$ & 0.547 & 0.513 & 1.679 \\
\hline
\end{tabular}

Sumber: Data Penelitian, 2020

Berdasarkan Tabel 3, dapat diketahui bahwa nilai $\mathrm{R}^{2}=54,7$ persen, yang berarti bahwa sebesar 54,7 persen Kinerja Pengawas Internal LPD di Kabupaten Klungkung dipengaruhi oleh variabel Independensi $\left(X_{1}\right)$,Motivasi $\left(X_{2}\right)$,Keahlian Profesional $\left(X_{3}\right)$, Tingkat Pendidikan $\left(X_{4}\right)$ Pengalaman Kerja $\left(X_{5}\right)$ dan sisanya sebesar 45,3 persen dipengaruhi oleh variabel lain yang tidak diteliti pada penelitian ini. Tabel 4, menunjukkan hasil perhitungan uji $F$ dengan menggunakan SPSS 21.

\section{Tabel 4. Hasil Uji F}

\begin{tabular}{lllllll}
\hline Model & & Sum of Squares & Df & Mean Square & F & Sig. \\
\hline \multirow{3}{*}{1} & Regression & 231.130 & 5 & 46.226 & 16.394 & $0.000^{\mathrm{b}}$ \\
& Residual & 191.735 & 68 & 2.820 & & \\
& Total & 422.865 & 73 & & &
\end{tabular}

Sumber: Data Penelitian, 2020

Berdasarkan hasil analisis, diketahui nilai signifikansi $\mathrm{F}$ adalah $0,000<0,05$, maka $\mathrm{H}_{0}$ ditolak. Hal ini berarti bahwa variabel Independensi $\left(\mathrm{X}_{1}\right)$, variabel Motivasi $\left(X_{2}\right)$, Keahlian Profesional $\left(X_{3}\right)$, Tingkat Pendidikan $\left(X_{4}\right)$ dan variabel pengalaman Kerja $\left(X_{5}\right)$ secara simultan berpengaruh signifikan terhadap Kinerja Pengawas Internal (Y) LPD di Kabupaten Klungkung, atau model yang digunakan dalam penelitian layak dan dapat dipergunakan untuk analisis berikutnya.

Berdasarkan hasil analisis dapat dijelaskan bahwa tingkat signifikansi variabel independensi $0,010<0,05$, sehingga $\mathrm{H}_{0}$ ditolak dan $\mathrm{H}_{a}$ diterima yang berarti bahwa variabel Independensi berpengaruh positif signifikan terhadap Kinerja Pengawas Internal. Koefisien regresi $\beta 1$ (variabel Independensi) sebesar 0,294, menunjukkan bahwa meningkatnya Independensi maka akan meningkatkan Kinerja Pengawas Internal LPD di Kabupaten Klungkung.

Berdasarkan hasil analisis dapat dijelaskan bahwa tingkat signifikansi variabel motivasi $0,036<0,05$ sehingga $\mathrm{H}_{0}$ ditolak dan $\mathrm{H}_{\mathrm{a}}$ diterima yang berarti bahwa variabel Motivasi berpengaruh positif signifikan terhadap Kinerja Pengawas Internal. Koefisien regresi $\beta 2$ (variabel Motivasi) sebesar 0,405, menunjukkan bahwa meningkatnya Motivasi maka akan meningkatkan Kinerja Pengawas Internal LPD di Kabupaten Klungkung.

Berdasarkan hasil analisis dapat dijelaskan bahwa tingkat signifikansi variabel keahlian profesional $0,000<0,05$, sehingga $\mathrm{H}_{0}$ ditolak dan $\mathrm{H}_{\mathrm{a}}$ diterima yang berarti bahwa variabel Keahlian Profesional berpengaruh positif signifikan terhadap Kinerja Pengawas Internal. Koefisien regresi $\beta 3$ (variabel Keahlian Profesional) sebesar 0,593 menunjukkan bahwa meningkatnya Keahlian Profesional maka akan meningkatkan Kinerja Pengawas Internal LPD di Kabupaten Klungkung.

Berdasarkan hasil analisis dapat dijelaskan bahwa tingkat signifikansi variabel tingkat pendidikan $0,026<0,05$, sehingga $\mathrm{H}_{0}$ ditolak dan $\mathrm{H}_{\mathrm{a}}$ diterima yang berarti bahwa variabel Tingkat Pendidikan berpengaruh positif signifikan 
terhadap Kinerja Pengawas Internal. Koefisien regresi $\beta 4$ (variabel Tingkat Pendidikan) sebesar 0,309 menunjukkan bahwa meningkatnya Tingkat Pendidikan maka akan meningkatkan Kinerja Pengawas Internal LPD di Kabupaten Klungkung .

Berdasarkan hasil analisis dapat dijelaskan bahwa tingkat signifikansi variabel pengalaman kerja $0,034<0,05$, sehingga $\mathrm{H}_{0}$ ditolak dan $\mathrm{H}_{\mathrm{a}}$ diterima yang berarti bahwa variabel Pengalaman Kerja berpengaruh positif signifikan terhadap Kinerja Pengawas Internal. Koefisien regresi $\beta 5$ (variabel Pengalaman Kerja) sebesar 0,228 menunjukkan bahwa meningkatnya Pengalaman Kerja maka akan meningkatkan Kinerja Pengawas Internal LPD di Kabupaten Klungkung.

Berdasarkan Tabel 2, dihasilkan tingkat signifikansi 0,010 $<0,05$. Berdasarkan nilai pengujian tersebut, dapat dilihat bahwa uji jatuh pada penolakan $\mathrm{H}_{0}$ ditolak dan $\mathrm{H}_{1}$ diterima untuk hipotesis pertama. Hal tersebut menyatakan penerimaan hipotesis yang bahwa terdapat pengaruh positif dan signifikan antara Independensi terhadap Kinerja Pengawas Internal LPD di Kabupaten Klungkung. Koefisien variabel $X_{1}$ adalah positif 0,294 artinya Independensi berpengaruh positif terhadap Kinerja Pengawas Internal.

Hasil penelitian ini sejalan dengan hasil penelitian yang dilakukan oleh (Widyantara et al., 2017) menyatakan dalam penelitiannya independensi berpengaruh positif terhadap kinerja badan pengawas LPD di kecamatan Buleleng. (Rahayu \& Suryono, 2016) dalam penelitiannya menyatakan bahwa seorang auditor dipengaruhi oleh independensi dalam menjalankan tugasnya. (Đorđević \& Đukić, 2017) menyatakan bahwa independensi berpengaruh positif pada efektivitas auditor internal. (Kodyawati \& Dewi, 2019) dalam penelitiannya menyatakan independensi berpengaruh positif terhadap kinerja pengawas.

Berdasarkan Tabel 2, tingkat signifikansi 0,036<0,05. Berdasarkan nilai pengujian tersebut dapat dilihat bahwa uji jatuh pada penolakan $\mathrm{H}_{0}$ ditolak dan $\mathrm{H}_{1}$ diterima untuk hipotesis kedua. Hal tersebut menyatakan penerimaan hipotesis yang bahwa terdapat pengaruh positif dan signifikan antara terhadap Kinerja Pengawas Internal LPD di Kabupaten Klungkung. Koefisien variabel $\mathrm{X}_{2}$ adalah positif 0,405, artinya Motivasi berpengaruh positif terhadap Kinerja Pengawas Internal. Apabila Motivasi meningkat, maka Kinerja Pengawas Internal akan meningkat sebesar 0,405.

Hasil penelitian ini sejalan dengan penelitian yang dilakukan oleh (Widyantara et al., 2017) menyebutkan bahwa salah satu factor yang mempengaruhi kinerja dari badan pengawas LPD di kecamatan Buleleng adalah motivasi. (Kodyawati \& Dewi, 2019) dalam penelitiannya menyatakan motivasi berpengaruh positif terhadap kinerja pengawas koperasi. Hal ini menyebabkann motivasi merupakan salah satu factor penting dalam kinerja pengawasan.

Berdasarkan Tabel 2, dihasilkan tingkat signifikansi 0,000 $<0,05$. Berdasarkan nilai pengujian tersebut, dapat dilihat bahwa uji jatuh pada penolakan $\mathrm{H}_{0}$ ditolak dan $\mathrm{H}_{1}$ diterima untuk hipotesis ketiga. Hal tersebut menyatakan penerimaan hipotesis yang bahwa terdapat pengaruh positif dan signifikan antara Keahlian Profesional terhadap Kinerja Pengawas Internal LPD di Kabupaten Klungkung. Koefisien variabel $X_{3}$ adalah positif 0,593 artinya Keahlian Profesional berpengaruh positif terhadap Kinerja Pengawas Internal. 
Apabila Keahlian Profesional meningkat maka Kinerja Pengawas Internal akan meningkat sebesar 0,593.

Hasil Penelitian ini sejalan dengan penelitian dari (Rahayu \& Suryono, 2016) dalam penelitiannya menyatakan bahwa keahlan professional berpengaruh positif terhadap kualitas kinerja auditor. (Mappanyuki, 2016) dalam penelitiannya menyebutkan bahwa keahlian professional berpengaruh positif terhadap kompleksitas kinerja seorang auditor. Penelitian (Wulandari \& Dharma, 2018) menunjukkan hasil profesionalisme berpengaruh positif dan signifikan terhadap kinerja internal auditor. (Putra \& Jati, 2019) hasil penelitiannya menyatakan profesionalisme berpengaruh positif dan signifikan pada kinerja pengawas internal LPD di Kecamatan Abiansemal Kabupaten Badung.

Berdasarkan Tabel 2, dihasilkan tingkat signifikansi 0,026< 0,05. Berdasarkan nilai pengujian tersebut, dapat dilihat bahwa uji jatuh pada penolakan $\mathrm{H}_{0}$ ditolak dan $\mathrm{H}_{1}$ diterima untuk hipotesis keempat. Hal tersebut menyatakan penerimaan hipotesis yang bahwa terdapat pengaruh positif dan signifikan antara Tingkat Pendidikan terhadap Kinerja Pengawas Internal LPD di Kabupaten Klungkung. Koefisien variabel $X_{4}$ adalah positif 0,309 , artinya Tingkat Pendidikan berpengaruh positif terhadap Kinerja Pengawas Internal. Apabila Tingkat Pendidikan meningkat, maka Kinerja Pengawas Internal akan meningkat sebesar 0,309.

Hasil penelitian ini sejalan dengan hasil penelitian (Widyantara et al., 2017) yang dilakukan pada pengawas LPD di kecamatan Buleleng. Variabel pendidikan dinyatakan berpengaruh positif terhadap kinerja pengawas LPD di kecamatan Buleleng. (Bouhawia et al., 2015) menyebutkan bahwa tingkat pendidikan berpengaruh pada hasil audit. Penelitian yang dilakukan (Kotur \& Anbazhagan, 2014) mengungkapkan bahwa factor pendidikan berpengaruh pada efektivitas kerja yang dilaksanakan. Hal ini juga didukung oleh penelitian yang dilakukan (Kodyawati \& Dewi, 2019) bahwa tingkat pendidikan berpengaruh positif dan signifikan terhadap kinerja pengawas. Sehingga, pendidikan sangat penting bagi auditor karena dengan pengetahuan yang dimiliki akan mempermudah dalam melakukan pemeriksaan audit.

Berdasarkan Tabel 2, dihasilkan tingkat signifikansi 0,034< 0,05. Berdasarkan nilai pengujian tersebut, dapat dilihat bahwa uji jatuh pada penolakan $\mathrm{H}_{0}$ ditolak dan $\mathrm{H}_{1}$ diterima untuk hipotesis kelima. Hal tersebut menyatakan penerimaan hipotesis yang bahwa terdapat pengaruh positif dan signifikan antara pengalaman kerja terhadap Kinerja Pengawas Internal LPD di Kabupaten Klungkung .Koefisien variabel $X_{5}$ adalah positif 0,228 , artinya pengalaman kerja berpengaruh positif terhadap Kinerja Pengawas Internal. Apabila pengalaman kerja meningkat, maka Kinerja Pengawas Internal akan meningkat sebesar 0,228 .

Hasil penelitian ini sejalan dengan penelitian yang dilakukan oleh (Kodyawati \& Dewi, 2019) yang menunjukan bahwa pengalaman kerja berpengaruh positif terhadap kinerja pengawas. (Kotur \& Anbazhagan, 2014) menyatakan bahwa pengalaman kerja akan meningkatkan efektivitas dalam bekerja namun pengalam kerja mengalami penurunan pada karyawan lama. (Bhuwaneswari \& Damayanthi, 2018) hasil penelitiannya menyatakan bahwa 
Pengalaman kerja terbukti berpengaruh positif pada efektivitas pengendalian internal LPD di Kota Denpasar. Hasil penelitian dari (Putra \& Jati, 2019) menyatakan pengalaman kerja berpengaruh positif dan signifikan pada kinerja pengawas internal LPD di Kecamatan Abiansemal Kabupaten Badung.

\section{SIMPULAN}

Hasil penelitian ini secara teoritis dapat memberikan gambaran serta tambahan pengetahuan yang berkaitan dengan pengaruh independensi, motivasi, keahlian professional, tingkat pendidikan dan pengalaman kerja terhadap kinerja pengawas internal. Serta memberikan tambahan informasi mengenai bagaimana perilaku seseorang dipengaruhi oleh faktor-faktor yang berasal dari dalam diri individu tersebut. Hal ini didukung oleh teori atribusi, dimana teori atribusi menjelaskan tingkah laku seseorang dipengaruhi antara kekuatan internal yaitu factor-faktor yang berasal dari dalam diri individu, seperti usaha atau kemampuan, serta kekuatan eksternal yaitu factor-faktor yang berasal dari lingkungan.

Implikasi praktis bagi seluruh pihak LPD di Kabupaten Klungkung melalui penelitian ini mampu memberikan tambahan pengetahuan serta informasi yang berkaitan dengan pengaruh independensi, motivasi, keahlian professional, tingkat pendidikan dan pengalaman kerja terhadap kinerja pengawas internal. sehingga kedepannya kinerja pengawas internal LPD Kabupaten Klungkung diharapkan semakin meningkat. Implikasi bagi pihak akademis melalui penelitian ini mampu memberikan bukti empiris mengenai pengaruh independensi, motivasi, keahlian professional, tingkat pendidikan dan pengalaman kerja terhadap kinerja pengawas internal.

\section{REFERENSI}

Bhuwaneswari, A. A. A. M., \& Damayanthi, G. A. E. (2018). Pengaruh Karakeristik Pengawas Internal terhadap Efektivitas Pengendalian Internal Lembaga Perkreditan Desa di Kota Denpasar. E-Jurnal Akuntansi, 22, 1800. https://doi.org/10.24843/EJA.2018.v22.i03.p06

Bouhawia, M. S., Irianto, G., \& Baridwan, Z. (2015). The Effect of Working Experience, Integrity, Competence, and Organizational Commitment on Audit Quality (Survey State Owned Companies In Libya). IOSR Journal of Economics and Finance Ver. II, 6(4), 2321-5933. https:/ / doi.org/10.9790/593306426067

Dedik, K., Herawati, N. T., \& Darmawan, N. A. S. (2014). Terhadap Perilaku Disfungsional Auditor (Studi Kasus pada Kantor Akuntan Publik di Provinsi Bali ). 1(1).

Dhiaa, S., \& Thuraiya, A. A. (2017). Factors Influence Internal Audit Effectiveness. International Journal of Business and Management. https://doi.org/10.5539/ijbm.v12n10p143

Đorđević, M., \& Đukić, T. (2017). Independence And Objectivity Of Internal Auditors As Determinants Of Their Effectiveness. Facta Universitatis, Series: Economics and Organization. https://doi.org/10.22190/fueo1703231d

Furiady, O., \& Kurnia, R. (2015). The Effect of Work Experiences, Competency, Motivation, Accountability and Objectivity towards Audit Quality. Procedia 
- Social and Behavioral Sciences. https:// doi.org/10.1016/j.sbspro.2015.11.042

Gamayuni, R. R. (2018). The effect of internal auditor competence and objectivity, and management support on effectiveness of internal audit function and financial reporting quality implications at local government. International Journal of Economic Policy in Emerging Economies. https://doi.org/10.1504/IJEPEE.2018.093951

Handoko, B. L., \& Marshella, M. (2020). Analysis of factors affecting audit report lag in the consumer goods industrial manufacturing company. International Journal of Innovation, Creativity and Change.

Herda, D. N., \& Martin, K. A. (2016). The effects of auditor experience and professional commitment on acceptance of underreporting time: A moderated mediation analysis. Current Issues in Auditing. https://doi.org/10.2308/ciia-51479

Imansari, P., Halim, A., \& Wulandari, R. (2016). Pengaruh Kompetensi, Independensi, Pengalaman dan Etika Auditor terhadap Kualitas Audit (Studi Empiris Pada Auditor Kantor Akuntan Publik Di Kota Malang). Jurnal Riset Mahasiswa Akuntansi Unikama.

Kodyawati, P., \& Dewi, L. G. K. (2019). Pengaruh Independensi Keahlian Profesi Motivasi Kerja Pengalaman Kerja Dan Tingkat Pendidikan Terhadap Kinerja Pengawas Koperasi. E-Jurnal Akuntansi, 27, 1597. https://doi.org/10.24843/ eja.2019.v27.i02.p29

Kotur, B. R., \& Anbazhagan, S. (2014). Education and Work-Experience Influence on the Performance. IOSR Journal of Business and Management. https://doi.org/10.9790/487x-1653104110

Krisnawati, N. P. A., \& Suartana, I. W. (2017). Pengaruh Kompetensi Karyawan, Motivasi Kerja, Komitmen Organisasi, Kemampuan Teknik Personal Terhadap Kinerja Sistem Informasi Akuntansi. E-Jurnal Akuntansi, 21, 25392566. https:// doi.org/10.24843/EJA.2017.v20.i03.p30

Mahendra, M. A., \& Ramantha, I. W. (2018). Pelatihan Kerja Memoderasi Pengaruh Tingkat Pendidikan dan Pengalaman Kerja Pada Efektivitas Pengendalian Internal. Jurnal Ilmiah Akuntansi Dan Bisnis, 2013, 65. https://doi.org/10.24843/JIAB.2018.v13.i01.p07

Mardika, I. B. A., \& Suartana, I. W. (2019). Pengaruh Independensi, Pengalaman Kerja, Komitmen Organisasi, dan Motivasi Auditor Pada Kualitas Audit. EJurnal Akuntansi, 27, 2211. https:// doi.org/10.24843/eja.2019.v27.i03.p21

Masrizal. (2010). Pengaruh Pengalaman Dan Pengetahuan Audit Terhadap Pendeteksian Temuan Kerugian Daerah (Studi Pada Auditor Inspektorat Aceh). Jurnal Telaah Dan Riset Akuntansi, 3(2), 173-194.

Mukuru, E., \& Kiruja, E. (2013). Effect of Motivation on Employee Performance In Public Middle Level Technical Training Institutions In Kenya. International Journal of Advances in Management and Economics, 16(3), 35-37.

Murtini, N. N., \& Juliarsa, I. G. (2017). Pengaruh Independensi, Keahlian Profesional, Pengalaman Kerja, Dan Tingkat Pendidikan Pada Kinerja Pengawas Koperasi. E-Jurnal Akuntansi, 20, 1390-1418. https:/ / doi.org/10.24843/EJA.2017.v20.i02.p19

Nasvita, D. M. (2016). The Factors That Effect On Internal Auditor Independence 
In The Aceh Banking Sector. Jurnal Ilmiah Peuradeun. https://doi.org/10.26811/peuradeun.v4i3.108

Nur, S. W., \& Fitri. (2017). The Influence of Independence and Competence of Auditor on The Performance of Inspectorate Auditors District MAROS. International Journal of Science and Research (IJSR). https://doi.org/10.21275/ ART20177179

Patrick, Z., Vitalis, K., \& Mdoom, I. (2017). Effect of Auditor Independence on Audit Quality: A Review of Literature. International Journal of Business and Management Invention ISSN.

Peraturan Daerah (PERDA) Provinsi Bali No. 3 Tahun 2017. Tentang Lembaga Perkreditan Desa

Peraturan Gubernur Bali Nomor 11 Tahun 2013 Tentang Petunjuk Pelaksanaan Peraturan Daerah Provinsi Bali Nomor 8 Tahun 2002 Tentang Lembaga Perkreditan Desa

Prawitasari, P. P., \& Badera, I. D. N. (2015). Pengaruh Independensi, Keahlian Profesional, Dan Pengalaman Kerja Pada Kinerja Pengawas Koperasi Serba Usaha. E-Jurnal Akuntansi, 11(1), 15-28.

Prasanti, D. H., Ramadhanti, W., \& Puspasari, N. (2019). Effect of Independence, Work Experience and Competence on Audit Quality with Professional Ethics as Moderating Variable. Jurnal Akuntansi Aktual. https://doi.org/10.17977/um004v5i32019p223

Putra, I. G. A., \& Jati, I. K. (2019). Analisis Pengaruh Profesionalisme, Independensi dan Pengalaman Kerja Pada Kinerja Pengawas Internal (Panureksa) LPD. E-Jurnal Akuntansi, 26, 1464. https://doi.org/10.24843/ eja.2019.v26.i02.p23

Putra, P. B. S., \& Rasmini, N. K. (2014). Pengaruh Independensi, Kompetensi, dan Ruang Lingkup Pekerjaan Audit Pengawas pada Efektivitas Pengendalian Intern Koperasi. E-Jurnal Akuntansi Universitas Udayana.

Rahayu, T., \& Suryono, B. (2016). Pengaruh Independensi Auditor , Etika Auditor , Dan Pengalaman Auditor Terhadap Kualitas Audit. Jurnal Ilmu Dan Riset Akuntasi.

Ratna Mappanyuki. (2016). Effects Spiritual Influence Of Auditors , Complexity Task, Ethics Auditor And Auditor Expertise On The Performance Auditor Withaccounting Information Systems With Moderating Variabel ( Empirical Study On Bpkp Representative Office South Sulawesi ). South East Asia Journal of Contemporary Bussines, Economics and Law, 9(1), 28-43.

Robbins, S. P., \& Timothy, A. J. (2015). Perilaku Organisasi Jilid II. Salemba Empat. https://doi.org/10.1097/ ACM.0b013e31821db670

Saleem, K. A. (2018). The Impact of Internal Audit Committees' Practices on Enhancing the Independence of Internal Auditors in Jordanian Commercial Banks. International Journal of Business and Management. https://doi.org/10.5539/ijbm.v13n5p156

Sihombing, Y. A., \& Triyanto, D. N. (2019). The Effect Of Independence, Objectivity, Knowledge, Work Experinece, Integrity, On Audit Quality (Study On West Java Provincial Inspectorate In 2018). Jurnal Akuntansi. https://doi.org/10.33369/j.akuntansi.9.2.141-160

St Ramlah, Syah, A., \& Dara, M. A. (2018). The effect of competence and 
independence to audit quality with auditor ethics as a Modernation variable. International Journal of Scientific and Technology Research.

Suartana, I. W. (2010). Akuntansi Keperilakuan, Teori dan Implementasi. In Yogyakarta.

Tawakkal, M. Y. R. (2019). The Effect of the Auditor?s Personal Characteristic on Audit Dysfunctionnal Behavior. International Journal of Science and Research (IJSR).

Tepalagul, N., \& Lin, L. (2015). Auditor Independence and Audit Quality: A Literature Review. In Journal of Accounting, Auditing and Finance. https://doi.org/10.1177/0148558X14544505

Usman. (2015). Effect Of Experience And Accountability On The Quality Of Internal Audit. International Journal of Scientific \& Technology Research, 4(8), 85-90.

Usman, A., Sudarma, M., Habbe, H., \& Said, D. (2014). Effect of Competence Factor, Independence and Attitude against Professional Auditor Audit Quality Improve Performance in Inspectorate (Inspectorate Empirical Study in South Sulawesi Province). IOSR Journal of Business and Management, 16(1), 01-13. https:// doi.org/10.9790/487x-16120113

Widyantara, I. N., Wahyuni, M. A., \& Atmadja, A. T. (2017). Pengaruh Independensi, Motivasi, Kompetensi, Dan Pengalaman Kerja Terhadap Kinerja Badan Pengawas Sebagai Auditor Internal Pada Lembaga Perkreditan Desa (Lpd) Di Kecamatan Buleleng. JIMAT (Jurnal Ilmiah Mahasiswa Akuntansi) Undiksha, 1(Vol 8, No 2 (2017):). https://ejournal.undiksha.ac.id/index.php/S1ak/article/view/13278

Wulandari, A. . S. G., \& Dharma, I. D. S. (2018). Pengaruh Profesionalisme Auditor, Komitmen Organisasi dan Etika Profesi Fakultas Ekonomi dan Bisnis Universitas Udayana ( Unud ), Bali , Indonesia Fakultas Ekonomi dan Bisnis Universitas Udayana ( Unud ), Bali , Indonesia Pada era globalisasi saat ini ba. E-Jurnal Akuntansi Universitas Udayana, 22(1), 273-300. https:// doi.org/ISSN: 2302-8556

Wulandari, L. R., \& Latrini, M. Y. (2018). Pengaruh Independensi, Pengalaman Kerja, Tingkat Pendidikan dan Pelatihan Kerja Terhadap Efektivitas Struktur Pengendalian Intern LPD. E-Jurnal Akuntansi, 22, 544. https://doi.org/10.24843/EJA.2018.v22.i01.p21

Yosep, M. (2016). Effect Competencies, Independence, Objectivity of the Function of Internal Audit (Implications for Quality Financial Reporting). European Journal of Accounting, Auditing and Finance Research. 